\title{
Perspektif Hukum Pidana Dalam Polemik Pengajuan Sumpah Advokat: Telaah Putusan Mahkamah Konstitusi Nomor 35/PUU-XVII/2018 Atas Surat Ketua Mahkamah Agung RI Nomor 73/KMA/HK.01/IX/2015
}

\author{
Faisal dan Muhammad Rustamaji \\ Fakultas Hukum Universitas Bangka Belitung Indonesia \\ Jln. Balunijuk, Merawang, Pangkalpinang, Provinsi Bangka Belitung Indonesia \\ Fakultas Hukum Universitas Sebelas Maret Surakarta Jawa Tengah Indonesia \\ JIn. Ir. Sutami 36A Kentingan, Jebres, Surakarta, Jawa Tengah, Indonesia 57126. \\ progresif_Ishp@yahoo.com; hatchi_ajie@yahoo.com \\ Received: 17 Juni 2020; Accepted: 20 Oktober 2020; Published: 15 Desember 2020 \\ https://doi.org/10.20885/iustum.vol27.iss3.art2

\begin{abstract}
The discussion regarding a single forum for advocates has been widely analyzed, but after the issuance of the Letter of the Chief Justice of the Supreme Court Number 73 / KMA / HK.01 / IX / 2015, the concept of a single container still leaves big questions. One of the questions in the realm of criminal law is whether the letter of the Chief Justice that allows an advocate organization other than PERADI to propose an Advocate oath to the High Court can be categorized as an act against criminal law and can be held criminally responsible at the same time? This type of normative legal research uses a conceptual approach and a case approach, especially with regard to judicial reviews. The collection of legal materials is carried out by studying the literature on primary legal materials and secondary legal materials. The results of the study concluded that the issuance of the Chief Justice of the Supreme Court No. 73/2015 which allowed advocacy organizations other than PERADI to propose an advocate's oath to the High Court could lead to acts against material criminal law. However, it is difficult to realize criminal liability for acts against criminal law due to the incomplete formulation, especially regarding the concept of contempt of court.
\end{abstract}

Key Words: Advocate oath; criminal responsibility; unlawful acts

\section{Abstrak}

\begin{abstract}
Pembahasan mengenai wadah tunggal advokat sudah banyak dianalisis, namun pasca-terbitnya Surat Ketua Mahkamah Agung Nomor 73/KMA/HK.01/IX/2015, konsep wadah tunggal masih menyisakan pertanyaan besar. Salah satu pertanyaan pada ranah hukum pidana adalah apakah surat Ketua MA yang mengizinkan organisasi advokat selain PERADI untuk mengusulkan sumpah Advokat ke Pengadilan Tinggi dapat dikategorikan perbuatan melawan hukum pidana dan sekaligus dapat dimintai pertanggungjawaban secara pidana? Jenis penelitian hukum normatif dengan pendekatan konseptual dan pendekatan kasus, utamanya berkenaan dengan judicial review. Pengumpulan bahan hukum dilakukan dengan studi pustaka terhadap bahan hukum primer dan bahan hukum sekunder. Hasil penelitian menyimpulkan, terbitnya Surat Ketua MA No 73/2015 yang mengizinkan organisasi advokat selain PERADI melakukan pengusulan sumpah advokat ke Pengadilan Tinggi dapat memunculkan perbuatan melawan hukum pidana materiil. Namun demikian, pertanggungjawaban hukum pidana terhadap perbuatan melawan hukum pidana tersebut sulit diwujudkan dikarenakan terjadinya rumusan yang tidak detail, utamanya mengenai konsep contempt of court.
\end{abstract}

Kata-kata Kunci: Perbuatan melawan hukum; pertanggungjawaban pidana; sumpah advokat 


\section{Pendahuluan}

Fokus tulisan ini memusatkan perhatiannya berdasarkan pada Surat Ketua Mahkamah Agung Nomor:73/KMA/HK.01/IX/2015 tertanggal 25 September 2015, yang "membukakan pintu"1 bagi Organisasi Advokat selain PERADI untuk mengusulkan penyumpahan calon advokat di Pengadilan Tinggi pada wilayah hukum domisilinya, menjadi isu hukum yang menarik untuk ditelaah lebih lanjut. Berpangkal tolak dari Surat Ketua MA ini, mengenai sistem organisasi tunggal profesi advokat atau single bar system ${ }^{2}$ seakan kembali disoal dan dipertanyakan. Bahkan, perdebatan mengenai organisasi advokat yang berwenang mengangkat advokat untuk selanjutnya dilaksanakan sumpah sebelum menggeluti profesinya sebagai advokat, kembali menghangat dan muncul ke permukaan.

Polemik terhadap relasi para pengemban profesi advokat demikian tentu dapat dipahami karena diantara delapan ${ }^{3}$ kewenangan yang telah diberikan oleh Undang Undang Nomor 18 Tahun 2003 tentang Advokat (UU Advokat), satu-satu hal yang tidak menjadi wewenang organisasi advokat adalah sumpah profesi advokat.Sumpah harus dilakukan di sidang terbuka Pengadilan Tinggi oleh calon advokat di wilayah domisili hukumnya. Akan tetapi, konsep hukum sebagaimana ketentuan Pasal 4 ayat (1) UU Advokat yang berkaitan dengan sumpah demikian, agaknya tidak konkruen dengan realitas yang terjadi di tataran sosiologis.

Kondisi demikian dapat digambarkan ketika Organisasi Advokat selain PERADI secara masif, simultan, dan terus-menerus mengajukan permohonan untuk dilaksanakannya sumpah profesi advokat ke Pengadilan Tinggi, meski hal tersebut sejatinya bukan menjadi wewenangnya. Pada kulminasi dan kondisi demikianlah Surat Ketua Mahkamah Agung Nomor: 73/KMA/HK.01/IX/2015 justru muncul sebagai sebuah permasalahan baru yang berpolemik. "Meminjam"

\footnotetext{
1 Angka 6 Surat Ketua Mahkamah Agung RI No 73/KMA/HK.01/IX/2015.

2 Samuel Saut Martua Samosir, "Organisasi Advokat dan Urgensi Peran Pemerintah dalam Profesi Advokat”, Jurnal Konstitusi, Volume 14, Nomor 3, September 2017, hlm.512

${ }^{3}$ Delapan kewenangan organisasi advokat yang diberikan oleh Undang Undang Nomor 18 Tahun 2003 tentang Advokat antara lain: a.melaksanakan Pendidikan Khusus Profesi Advokat [Pasal 2 ayat (1)]; b.melaksanakan pengujian calon Advokat Pasal 3 ayat (1) huruf f]; c.melaksanakan pengangkatan Advokat [Pasal 2 ayat (2)]; d.membuat kode etik [Pasal 26 ayat (1)]; e.membentuk Dewan Kehormatan [Pasal 27 ayat (1)]; f.membentuk Komisi Pengawas [Pasal 13 ayat (1)]; g.melakukan pengawasan [Pasal 12 ayat (1)]; dan h.memberhentikan Advokat [Pasal 9 ayat (1)].
} 
istilah Jean Baudrillard, kondisi polemik penyumpahan advokat demikian disebut sebagai simulacra, yaitu realitas yang ada adalah realitas maya, realitas semu, realitas buatan (hyper-reality). ${ }^{4}$

Demikian pula dikatakan oleh Charles Sampford sebagai "legal melee" hukum selalu keadaan cair (fluid). Skema dan hubungan hukum yang dirumuskan dengan eksplisit dalam aturan hukum tidak menghilangkan sifat melee dibelakangnya yaitu terdapat interaksi antar manusia yang menentukan makna dibalik teks hukum yang ditafsirkan kembali oleh konteksnya. Pada akhirnya yang muncul adalah keadaan yang kompleks, cair, dan penuh dengan ketidakteraturan. ${ }^{5}$

Begitulah memandang hakikat komunikasi masa yang dalam hal ini dipasangkan dalam perhelatan beragam pandangan mengenai persoalan penyumpahan advokat pasca-terbitnya Surat Ketua Mahkamah Agung Nomor: 73/KMA/HK.01/IX/2015. Pada kondisi demikian, terjadi suatu fenomena yang sejatinya justru mengaburkan realitas organisasi advokat yang sesungguhnya mempunyai wewenang dalam prosesi demikian.

Sementara di saat yang berbeda, Mahkamah Konstitusi secara konsisten telah menjatuhkan putusan berkenaan dengan sengkarut organisasi advokat demikian dalam berbagai putusannya. ${ }^{6}$ Bahkan, pada putusan yang terbaru, yaitu Putusan Mahkamah Konstitusi Nomor 35/PUU-XVII/2018 tertanggal 28 November 2019, dapat dicermati bahwa meskipun amar putusan Mahkamah Konstitusi menolak permohonan para Pemohon, namun dalam pertimbangannya antara lain menyatakan bahwa dengan telah terbentuknya PERADI yang merupakan satu-satunya wadah profesi advokat,7 maka sudah seharusnya tidak ada lagi persoalan konstitusionalitas organisasi advokat.

${ }^{4}$ Lusius Sinurat, 'Simulacra dan Realitas Semu', www.lusius-sinurat.com/2013/07/simulacra-dan-realitas$\underline{\text { semu }}$, diunduh 8 Oktober 2019. Muhammad Rustamaji "Simulacra Asas Praduga Tidak Bersalah dalam Ingsutan Kewenangan Praperadilan” Yustisia Jurnal Hukum, Volume5, Issue2, 2016, h.435-447.

5 Faisal, "Menelusuri Teori Chaos Dalam Hukum Melalui Paradigma Critical Theory", Jurnal Hukum Yustisia, Volume 3 Nomor 2, Mei-Agustus 2014, hlm 132

6 Putusan Mahkamah Konstitusi Nomor 014/PUU-IV/2006 bertanggal 30 November 2006, Putusan Mahkamah Konstitusi Nomor 101/PUU-VII/2009 bertanggal 30 Desember 2009, Putusan Mahkamah Konstitusi Nomor 66/PUU-VIII/2010 bertanggal 27 Juni 2011, serta Putusan Mahkamah Konstitusi Nomor 112/PUU-XII/2014 dan Putusan Mahkamah Konstitusi Nomor 36/PUU-XIII/2015 bertanggal 29 September 2015.

7 Putusan Mahkamah Konstitusi Nomor 35/PUU-XVII/2018, hlm. 252 
Berdasarkan kondisi diametral terhadap penyumpahan profesi advokat yang ditimbulkan sebagai konsekuensi logis pasca-terbitnya Surat Ketua Mahkamah Agung Nomor 73/KMA/HK.01/IX/2015 dan Putusan Mahkamah Konstitusi Nomor 35/PUU-XVII/2018, pertanyaan yang selanjutnya bermunculan pada ranah hukum pidana, antara lain; apakah surat Ketua Mahkamah Agung RI Nomor 73/KMA/HK.01/IX/2015 Perihal Penyumpahan Advokat berpotensi memunculkan perbuatan melawan hukum pidana? Apakah organisasi advokat selain PERADI atas pengusulan sumpah Advokat ke Pengadilan Tinggi dapat berpotensi melakukan perbuatan melawan hukum pidana? Bagaimana pertanggungjawaban hukum pidana terhadap surat Ketua Mahkamah Agung RI Nomor 73/KMA/HK.01/IX/2015 Perihal Penyumpahan Advokat? Bagaimana pertanggungjawaban hukum pidana terhadap organisasi advokat selain PERADI atas pengusulan sumpah Advokat ke Pengadilan Tinggi Pasca Putusan Mahkamah Konstitusi Nomor 35/PUU-XVII/2018?

Mencermati beragam pertanyaan yang muncul demikian, telaah secara lebih mendalam mengenai kedua produk hukum dari dua puncak lembaga peradilan tersebut menjadi urgen untuk dilakukan. Penelitian lebih lanjut terhadap Surat Ketua Mahkamah Agung Nomor 73/KMA/HK.01/IX/2015 juga relevan untuk dilakukan karena penelitian-penelitian terdahulu belum menyentuh analisis terkait aspek perbuatan melawan hukum pidana dan pertanggungjawaban pidana dari diterbitkannya aturan tersebut, sebagaimana dilakukan dan disajukan melalui penelitian ini.

\section{Rumusan Masalah}

Guna memfokuskan kajian penelitian yang dilakukan, dirumuskan sebuah perumusan masalah, yaitu apakah Surat Ketua Mahkamah Agung Nomor 73/KMA/HK.01/IX/2015, yang mengizinkan organisasi advokat selain PERADI untuk mengusulkan sumpah Advokat ke Pengadilan Tinggi, dapat dikategorikan sebagai perbuatan melawan hukum pidana dan sekaligus dapat dimintai pertanggungjawaban secara pidana? 


\section{Tujuan Penelitian}

Tujuan penelitian ini adalah memberikan jawaban analitis berkenaan dengan problematika teoretis hukum akibat munculnya Surat Ketua Mahkamah Agung Nomor 73/KMA/HK.01/IX/2015 pasca-Putusan Mahkamah Konstitusi Nomor 35/PUU-XVII/2018, yang mengizinkan organisasi advokat selain PERADI untuk mengusulkan sumpah Advokat ke Pengadilan Tinggi dalam perspektif perbuatan melawan hukum pidana.

\section{Metode Penelitian}

Jenis penelitian hukum yang digunakan merupakan metode penelitian hukum normatif. Penelitian hukum normatif dalam riset ini difokuskan pada taraf sinkronisasi hukum. ${ }^{8}$ Penelitian hukum dimaksud dilakukan dengan pendekatan konseptual dan kasus, utamanya berkenaan dengan judicial review.

Pendekatan konseptual dioptimalkan untuk menggali dan mengkaji secara teoretik konsep perbuatan melawan hukum pidana dan pertanggungjawaban pidana atas terbitnya Surat Ketua Mahkamah Agung RI No 73/KMA/HK.01/IX/2015. Sementara pendekatan kasus dimanfaatkan untuk mengakaji dan menganalisis secara kiritis Putusan Mahkamah Konstitusi Nomor 35/PUU-XVII/2018, dan penyajian dalam bagian pembahasan yang dijelaskan dalam suatu analisis berkenaan dengan judicial review yang melatarbelakanginya.

Pengumpulan bahan hukum dilakukan melalui studi pustaka dengan meneliti bahan hukum primer dan bahan hukum sekunder. Bahan hukum primer dalam penulisan ini seperti Putusan Mahkamah Konstitusi Nomor 35/PUUXVII/2018 dan Surat Ketua Mahkamah Agung RI No 73/KMA/HK.01/IX/2015. Bahan hukum sekunder meliputi bahan kepustakaan, baik buku, jurnal, dan doktrin yang berkait dengan isu hukum yang dikaji.

\footnotetext{
${ }^{8}$ Soerjono Seokanto mengetengahkan bahwa penelitian normatif terdiri dari penelitian terhadap asas-asas hukum, penelitian terhadap sistematika hukum, penelitian terhadap taraf sinkronisasi hukum, penelitian sejarah hukum, dan penelitian perbandingan hukum, dalam Derita Prapti Rahayu dan Sulaiman, Metode Penelitian Hukum, Thafa Media, Yogyakarta, 2020, hlm. 80
} 


\section{Hasil Penelitian dan Pembahasan}

Analisis Potensi Perbuatan Melawan Hukum Pidana dan Kajian Pertanggungjawaban Hukum Pidana atas Terbitnya Surat Ketua Mahkamah Agung RI No.73/KMA/HK.01/IX/2015

Sehubungan dengan terbitnya Surat Ketua Mahkamah Agung RI No. 73/KMA/HK.01/IX/2015, yang notabene membuka peluang bagi setiap organisasi advokat selain PERADI untuk mengusulkan penyumpahan calon advokat di sidang terbuka Pengadilan Tinggi pada wilayah hukum domisilinya, berpotensi menimbulkan permasalahan hukum. Akan tetapi, apakah potensi demikian benar-benar terjadi dan apakah permasalahan hukum tersebut berkesesuaian dengan konsep perbuatan melawan hukum pidana maupun pertanggungjawaban pidana? Hal inilah yang selanjutnya menjadi fokus kajian pada pembahasan dimaksud.

Sebelum mengkaji letak permasalahan hukum pada ranah pidana, patut diungkap terlebih dahulu pisau analisis yang digunakan untuk mengupas isu hukum atas terbitnya Surat Ketua MA dimaksud. Analisis demikian tentu saja berkait erat dengan telaah teoretik terhadap konsep perbuatan melawan hukum pidana maupun pertanggungjawaban pidana.

Selanjutnya kajian ini secara berturut-turut mengulas terlebih dahulu mengenai dugaan terjadinya perbuatan melawan hukum pidana atas terbitnya Surat Ketua Mahkamah Agung RI No. 73/KMA/HK.01/IX/2015, dan pada tahap selanjutnya diulas mengenai aspek pertanggungjawaban pidananya.

1. Kajian Dugaan Terjadinya Perbuatan Melawan Hukum Pidana atas Terbitnya Surat Ketua Mahkamah Agung RI No 73/KMA/HK.01/IX/2015

Berdasarkan pembacaan atas beragam referensi mengenai hukum pidana, perbuatan melawan hukum atau biasa disingkat PMH acapkali lebih dikenal berada pada ranah hukum perdata ${ }^{9}$. Konsep keperdataan demikian semakin kental dirasakan ketika digunakan diksi "gugatan perbuatan melawan hukum". Namun demikian, PMH sejatinya juga dikenal pada ranah hukum pidana. Oleh karenanya, meskipun berada pada dua ranah yang berbeda, inti dari konsep hlm. 22

${ }_{9}^{9}$ Munir Fuady, Perbuatan Melawan Hukum (Pendekatan Kontemporer), PT. Citra Aditya Bakti, Bandung, 2005, 
PMH, baik pada ranah hukum perdata maupun hukum pidana, sejatinya samasama berkaitan erat dengan pelanggaran hukum.

Ketika mencermati perkembangannya, PMH pada ranah hukum perdata justru mengalami penafsiran secara luas yang tidak hanya berkenaan dengan pelanggaran hukum dalam ketentuan undang-undang. PMH pada konteks hukum keperdataan juga diartikan melanggar hak orang lain, bertentangan dengan kewajiban hukum sang subjek hukum, bertentangan dengan kesusilaan, dan bertentangan dengan kepentingan umum. Hal demikian tentu saja sedikit berbeda dari konsep PMH pada ranah hukum pidana yang berkutat pada pelanggaran hukum dalam ketentuan undang-undang. ${ }^{10}$

Mengenai perbedaan lebih lanjut antara PMH pada ranah hukum perdata dengan PMH pada ranah hukum pidana dapat dicermati berdasarkan beberapa faktor. Pertama, berkait dengan peristilahan. Pada ranah hukum perdata, PMH disebut dengan istilah onrechtmatige daad, sedangkan pada ranah hukum pidana disebut wederrechtelijk. Kedua, berkenaan dengan sifatnya. Sejalan dengan karakteristik dan sifat hukum pidana sebagai hukum publik, maka PMH pada ranah hukum pidana berkaitan erat dengan kepentingan umum yang dilanggar. Sementara, mengingat hukum perdata yang notabene mempunyai sifat hukum privat, PMH pada ranah hukum perdata berkorelasi dengan pelanggaran terhadap kepentingan pribadi.

Mengerucut pada konteks hukum pidana, menurut Satochid Kartanegara, "melawan hukum" (wederrechtelijk) dalam hukum pidana dibedakan menjadi dua, ${ }^{11}$ yaitu (a) wederrechtelijk formiil, yaitu apabila sesuatu perbuatan dilarang dan diancam dengan hukuman oleh undang-undang 12 dan (b) wederrechtelijk materiil, yaitu sesuatu perbuatan yang dikategorikan wederrechtelijk, walaupun

${ }^{10} \mathrm{Ibid}$, hlm. 22

${ }^{11}$ Satochid Kartanegara, Hukum Pidana Bagian Pertama, Balai Lektur Mahasiswa, Jakarta, 1955, hlm. 6

12 Bandingkan dengan pendapat Zainal Abidin yang menjelaskan bahwa wederrechtelijk dikatakan formil karena undang-undang melarang atau memerintahkan perbuatan itu disertai ancaman sanksi kepada barang siapa yang melanggar atau mengabaikannya. Arti perbuatan melawan hukum formil adalah unsur-unsur yang bersifat konstitutif, yaitu setiap unsur yang ada dalam setiap rumusan delik dalam aturan pidana tertulis, walaupun dalam kenyataan formulasinya tidak dituliskan dengan tegas bersifat melawan hukum. Dengan demikian dalam hal tidak dicantumkan berarti unsur melawan hukum diterima sebagai unsur kenmerk (diterima secara diam-diam, implisit). Melawan hukum formil lebih mementingkan kepastian hukum (rechtszekerheids) yang bersumber dari asas legalitas (principle of legality, legaliteit benginsel). H.A. Zainal Abidin Farid, Hukum Pidana I, Sinar Grafiika, Jakarta, 2007, hlm. 242. 
tidak dengan tegas dilarang dan diancam dengan hukuman oleh undang-undang, melainkan juga mencakup asas-asas umum yang terdapat di dalam lapangan hukum (algemen beginsel). Lebih lanjut, Schaffmeister, sebagaimana dikutip oleh Andi Hamzah, berpendapat bahwa "melawan hukum" yang tercantum di dalam rumusan delik yang menjadi bagian inti delik disebut sebagai "melawan hukum secara khusus." Contohnya ada pada Pasal $372^{13}$ Kitab Undang-Undang Hukum Pidana (KUHP).Sedangkan "melawan hukum" sebagai unsur yang tidak disebut dalam rumusan delik, tetapi menjadi dasar untuk menjatuhkan pidana, disebut sebagai "melawan hukum secara umum." Contohnya ada pada Pasal $351^{14}$ KUHP. 15

Berdasarkan konsepsi mengenai PMH pada ranah hukum pidana tersebut, ketika pisau analisis demikian diarahkan pada Surat Ketua Mahkamah Agung RI No 73/KMA/HK.01/IX/2015 sebagai objek telaah, hal pertama yang harus diungkap adalah apakah terdapat pelanggaran hukum terhadap ketentuan undang-undangyang sebelumnya sudah ada? Dengan lain perkataan, pertanyaan demikian sejatinya diarahkan untuk mencari kejelasan mengenai adakah asas legalitas yang diterobos dengan terbitnya Surat Ketua MA tersebut?

Pertanyaan demikian relatif mudah untuk ditemukan jawabannya ketika mencermati point 6 Surat Ketua Mahkamah Agung RI No 73/KMA/HK.01/IX/2015 yang menyebutkan:

"bahwa terhadap Advokat yang belum bersumpah atau berjanji, Ketua Pengadilan Tinggi berwenang melakukan penyumpahan terhadap Advokat yang memenuhi persyaratan dalam Pasal 2 dan Pasal 3 Undang-Undang Nomor 18 Tahun 2003 atas permohonan dari beberapa Organisasi Advokat yang mengatasnamakan Peradi dan pengurus Organisasi Advokat lainnya hingga terbentuknya UU Advokat yang baru."

13 Rumusan Pasal 372 KUHP: "Barang siapa dengan sengaja dan melawan hukum memiliki barang sesuatu yang seluruhnya atau sebagian adalah kepunyaan orang lain, tetapi yang ada dalam kekuasaannya bukan karena kejahatan diancam karena penggelapan, dengan pidana penjara paling lama empat tahun atau pidana denda paling banyak sembilan ratus rupiah". Contoh lain yang menunjukkan PMH secara khusus dapat ditemukan pada Pasal 2 Undang-Undang No. 31 Tahun 1999 Jo. Undang-Undang No. 20 Tahun 2001 tentang Pemberantasan Tindak Pidana Korupsi (UU Tipikor) yang memuat unsur melawan hukum.

${ }^{14}$ Rumusan Pasal 351 ayat (1) KUHP: "Penganiayaan dihukum dengan hukuman penjara selama-lamanya dua tahun delapan bulan atau denda sebanyak-banyaknya Rp 4.500”. Contoh senada dengan Pasal 351 ayat (1) KUHP demikian dpat ditemukan pada Pasal 3 Undang-Undang No. 31 Tahun 1999 Jo. Undang-Undang No. 20 Tahun 2001 tentang Pemberantasan Tindak Pidana Korupsi (UU Tipikor) yang tidak secara tekstual mencantumkan unsur "melawan hukum".

15 Andi Hamzah, Pengantar dalam Hukum Pidana Indonesia, Yarsif Watampone, Jakarta. 2010, hlm 168 
Ketentuan point 6 Surat Ketua Mahkamah Agung RI No. 73/KMA/HK.01/IX/2015demikian secara jelas bertumbukkan dengan kepastian hukum ketentuan Pasal 1 angka $4^{16}$ dan Pasal 28 ayat (1) UU Advokat. ${ }^{17}$

Konteks kepastian hukum, kedua pasal dalam UU Advokat yang coba disimpangi oleh terbitnya Surat Ketua Mahkamah Agung RI No. 73/KMA/HK.01/IX/2015, dapat dibedah dengan pisau analisis telaah teoretik sebagaimana dikemukakan oleh Jan Michiel Otto. Dapat dikemukakan bahwa kedudukan PERADI, sebagai wadah tunggal Organisasi Advokat, telah memenuhi kerangka paradigmatik kepastian hukum menurut Jan Michiel Ottoyang mencakup: 18

a. Tersedia aturan yang jelas (jernih), konsisten, dan mudah diperoleh (accessible), serta diterbitkan dan diakui karena kekuasaan negara. Pada konteks ini, ketentuan Pasal 1 angka 4 dan Pasal 28 ayat (1) UU Advokat menjadi asas legalitas,sebagai "pagar yang kukuh" atas eksistensi PERADI sebagai wadah tunggal organisasi advokat yang dituangkan dalam bentuk undang-undang.

b. Instansi-instansi menerapkan aturan-aturan hukum tersebut secara konsisten. Pada konteks ini, berdasarkan Pasal 28 ayat (1) UU Advokat, hanya ada satu atau disebut satu-satunya Organisasi Advokat, yaitu Perhimpunan Advokat Indonesia (PERADI), yang telah dibentuk dan didirikan oleh delapan organisasi ${ }^{19}$ pada 21 Desember 2004 yang masih berada dalam kurun waktu tidak lebih dari dua tahun setelah UU Advokat diundangkan sebagaimana disebutkan pada Pasal 32 ayat (3) UU Advokat. Regulasi ini yang menjadi tiga alasan kuat mengenai eksistensi PERADI sebagai wadah tunggal organisasi advokat, baik ditinjau dari waktu pendirian Organisasi Advokat, subjek hukum yang mendirikan Organisasi Advokat, maupun hasil wadah tunggal sebagai Organisasi Advokat.

c. Warga negara menyesuaikan perilaku mereka terhadap aturan-aturan tersebut. Pada konteks ini, setiap warga negara yang berkeinginan menggeluti profesi advokat, harus memenuhi ketentuan Pasal 2 ayat (1)dan Pasal 3 ayat (1) UU Advokatsertamelaksanakan sumpah advokat sebagaimana ketentuan Pasal 4 ayat (1) UU Advokat.

${ }_{16}$ Pasal 1 angka 4 UU Advokat: Organisasi Advokat adalah organisasi profesi yang didirikan berdasarkan Undang-Undang ini.

17 Pasal 28 ayat (1) UU Advokat: Organisasi Advokat merupakan satu-satunya wadah profesi Advokat yang bebas dan mandiri yang dibentuk sesuai dengan ketentuan Undang-Undang ini dengan maksud dan tujuan untuk meningkatkan kualitass profesi Advokat.

18 Jan Michiel Otto terjemahan Tristam Moeliono dalam Shidarta, Moralitas Profesi Hukum Suatu Tawaran Kerangka Berfikir, PT Revika Aditama, Bandung, 2006, hlm. 85.

${ }^{19}$ Ikatan Advokat Indonesia (IKADIN), Asosiasi Advokat Indonesia (AAI), Ikatan Penasihat Hukum Indonesia (IPHI), Himpunan Advokat dan Pengacara Indonesia (HAPI), Serikat Pengacara Indonesia (SPI), Asosiasi Konsultan Hukum Indonesia (AKHI), Himpunan Konsultan Hukum Pasar Modal (HKHPM) dan Asosiasi Pengacara Syariah Indonesia (APSI). 
d. Hakim-hakim (peradilan) yang mandiri dan tidak berpihak menerapkan aturan-aturan hukum tersebut secara konsisten sewaktu mereka menyelesaikan sengketa hukum. Pada konteks ini, konsistensi Putusan Mahkamah Konstitusi Nomor 014/PUU-IV / 2006 bertanggal 30 November 2006, Putusan Mahkamah Konstitusi Nomor 101/PUU-VII/2009 bertanggal 30 Desember 2009, Putusan Mahkamah Konstitusi Nomor 66/PUU-VIII/2010 bertanggal 27 Juni 2011, Putusan Mahkamah Konstitusi Nomor 112/PUU-XII/2014, Putusan Mahkamah Konstitusi Nomor 36/PUU-XIII/2015 bertanggal 29 September 2015 bahkan hingga Putusan Mahkamah Konstitusi Nomor 35/PUU-XVII/2018, menunjukkan penguatan atas PERADI sebagai wadah tunggal organisasi advokat, dan

e. Keputusan peradilan dilaksanakan secara konsisten.

Mengikuti pandangan Jan Michiel Otto demikian, dalam dimensi lain dapat diungkapkan bahwa kepastian hukum merupakan sicherkeit des rechts selbst, yaitu kepastian tentang aturan hukum itu sendiri. Oleh karena itu, dialektika dan adu argumentasi yang panjang sejak UU Advokat lahir hingga saat ini sejatinya memberi gambaran mengenai kepastian hukum yang harus memenuhi empat syarat, yaitu pertama, hukum itu bersifat positif artinya hukum tersebut merupakan norma perundang-undangan. Kedua, hukum itu berdasarkan fakta (tatchachen), bukan merupakan suatu rumusan tentang penilaian. Ketiga, fakta hukum harus dirumuskan secara jelas sehingga mencegah kekeliruan dalam penafsiran serta mudah dijalankan. Keempat, hukum berjangka waktu lama (durable), tidak terlalu sering diubah-ubah.

Ketika ulasan ketentuan point 6 Surat Ketua Mahkamah Agung RI No. 73/KMA/HK.01/IX/2015sangat jelas bertumbukkan dengan kepastian hukum ketentuan Pasal 1 angka 4 dan Pasal 28 ayat (1) UU Advokat, maka dalam perspektif hukum pidana dapat disimpulkan telah terjadi perbuatan "melawan hukum" (Wederrechtelijk). Ketika ditelaah berdasarkan pandangan Satochid Kartanegara, perbuatan "melawan hukum" (wederrechtelijk) demikian terkategori sebagai wederrechtelijk materiil, yaitu sesuatu perbuatan yang dikategorikan wederrechtelijk, walaupun tidak dengan tegas dilarang dan diancam dengan hukuman oleh undang-undang. Melainkan, terbitnya Surat Ketua Mahkamah Agung RI No 73/KMA/HK.01/IX/2015 telah melanggar asas-asas umum yang terdapat di dalam lapangan hukum (algemen beginsel), utamanya asas kepastian 
hukum. Adapun dalam kacamata Schaffmeister, perbuatan "melawan hukum" demikian disebut sebagai "melawan hukum secara umum". Hal demikian dikarenakan diksi "melawan hukum" tidak tercantum dalam Pasal 1 angka 4 dan Pasal 28 ayat (1) UU Advokat sebagai unsur dalam rumusan delik ketika undangundang ini disimpangi ketentuannya.

\section{Kajian Pertanggungjawaban Pidana atas Terbitnya Surat Ketua Mahkamah Agung RI Nomor 73/KMA/HK.01/IX/2015}

Pertanggungjawaban pidana merupakan pengenaan hukuman terhadap pelaku karena perbuatan yang dilakukannya telah melanggar larangan atau menimbulkan keadaan yang terlarang. Oleh karenanya, pertanggungjawaban pidana menyangkut proses peralihan hukuman yang ada dari tindak pidana kepada pelakunya. Upaya mempertanggungjawabkan seseorang dalam hukum pidana merupakan langkah meneruskan hukuman yang secara objektif telah diatur yang selanjutnya disinkronkan dengan perbuatan pidana secara subjektif terhadap pembuatnya. Pertanggungjawaban pidana ditentukan berdasarkan kesalahan pelaku dan bukan hanya didasarkan dengan dipenuhinya seluruh unsur tindak pidana. Dengan demikian, kesalahan ditempatkan sebagai faktor penentu pertanggungjawaban pidana dan tidak hanya dipandang sebagai sekedar unsur mental dalam tindak pidana. ${ }^{20}$ Ketika seseorang dinyatakan mempunyai kesalahan, poin kesalahan ini yang merupakan perihal yang menyangkut masalah pertanggungjawaban pidana. ${ }^{21}$

Oleh karenanya, untuk dapat mengenakan pidana pada pelaku karena melakukan tindak pidana, aturan hukum mengenai pertanggungjawaban pidana berfungsi sebagai penentu syarat-syarat yang harus ada pada diri seseorang, sehingga sah dalam perspektif hukum jika dijatuhi hukuman.

Pertanggungjawaban pidana menyangkut masalah pelaku tindak pidana, sedangkan aturan mengenai pertanggungjawaban pidana merupakan regulasi mengenai bagaimana memperlakukan seseorang yang melanggar kewajiban ${ }^{22}$. Jadi, perbuatan yang dilarang oleh masyarakat dipertanggungjawabkan pada si

${ }^{20}$ Chairul Huda, Dari Tiada Pidana Tanpa Kesalahan Menuju Kepada Tiada Pertanggungjawaban Pidana Tanpa Kesalahan, Kencana Prenada Media, Jakarta, 2006, hlm. 4.

${ }^{21}$ Admaja Priyatno, Kebijakan Legislasi Tentang Sistem Pertanggungjawaban Pidana Koorporasi di Indonesia, CV. Utomo, Bandung, 2004, hlm. 15.

${ }^{22}$ Ibid 
pembuatnya. Artinya, hukuman yang objektif terhadap hukuman itu kemudian diteruskan kepada si pelaku.

Pertanggungjwaban pidana tanpa adanya kesalahan dari pihak yang melanggar tentu saja tidak dapat dipertanggungjawaban ${ }^{23}$. Adagium tiada pidana tanpa kesalahan dalam hukum lazimnya dipakai dalam arti tiada pidana tanpa kesalahan subyektif atau kesalahan tanpa dapat dicela. Akan tetapi dalam hukum pidana, orang tidak dapat berbicara tentang kesalahan tanpa adanya perbuatan yang tidak patut. Karena itu, asas kesalahan diartikan sebagai tiada pidana tanpa perbuatan tidak patut yang obyektif, yang dapat dicelakan kepada pelakunya. ${ }^{24}$

Dengan lain perkataan, seseorang tidak mungkin dipertanggungjawabkan dan dijatuhi pidana apabila yang bersangkutan tidak melakukan perbuatan pidana. Namun demikian, meskipun seseorang melakukan perbuatan pidana tidak selalu yang bersangkutan dapat dipidana.

Menurut pandangan van Hamel yang menyatakan bahwa pertanggungjawaban pidana merupakan suatu keadaan normal dan kematangan psikis yang membawa tiga macam kemampuan untuk: (a) memahami arti dan akibat perbuatannya sendiri, (b) menyadari bahwa perbuatannya itu tidak dibenarkan atau dilarang oleh masyarakat, dan (c) menentukan kemampuan terhadap perbuatan. ${ }^{25}$

Moeljatno menyatakan pertanggungjawaban pidana tidak cukup dengan dilakukannya perbuatan pidana saja, akan tetapi di samping itu harus ada kesalahan, atau sikap batin yang dapat dicela, ternyata pula dalam asas hukum yang tidak tertulis tidak dipidana jika tidak ada kesalahan (green straf zonder schuld, ohne schuld keine strafe). ${ }^{26}$

Pada konteks terbitnya Surat Ketua Mahkamah Agung RI No. 73/KMA/HK.01/IX/2015 sebagai objek telaah, pandangan van Hamel sejatinya

${ }^{23}$ I. Sriyanto, "Asas Tiada Kesalahan dalam Pertanggungjawaban Pidana dengan Penyimpangannya", Jurnal Hukum dan Pembangunan, Nomor 2 Tahun XXIII, April 1993, hlm. 158

${ }^{24}$ Faisal, 2020, Politik Hukum Pidana, Tangerang, Rangkang Education, hlm. 39

${ }^{25}$ G.A. van Hamel, Inleiding Tot De Studie Van Het Nederlansche Strafrecht, Derde Druk, De Erven F. Bohn Haarlem \& Gebr. Belinfante's-Gravenhage. 1913, hlm. 387. Eddy O.S. Hiariej, Prinsip-prinsip Hukum Pidana, Cahaya Atma Pustaka-UAJY, Yogyakarta, 2014, hlm 121. Admaja Priyatno, Kebijakan Legislasi...Loc.Cit.

${ }^{26}$ Diah Gustiniati Maulani, "Analisi Pertanggungjawaban Pidana dan Dasar Pemidanaan Terhadap Pelaku Tindak Pidana Penodaan Agama Di Indonesia", Fiat Justitia Jurnal Ilmu Hukum, Volume 7 Nomor 1, JanuariApril 2013, hlm 4 
mendapatkan konfirmasi secara parsial. Berkenaan dengan aspek "memahami arti dan akibat perbuatannya sendiri," Ketua MA sudah seharusnya memahami bahwa surat demikian menyimpangi ketentuan UU Advokat, kususnya berkenaan dengan wadah tunggal organisasi advokat. Akibatnya, Surat Ketua Mahkamah Agung RI No. 73/KMA/HK.01/IX/2015tidak memberikan kepastian hukum berkenaan dengan prosedur pengajuan permohonan sumpah advokat oleh wadah tunggal Organisasi Advokat, sebagai konsekuensi diperbolehkannya semua organisasi profesi advokat untuk mengajukan permohonan sumpah advokat.

Terhadap aspek "menyadari bahwa perbuatannya itu tidak dibenarkan atau dilarang oleh masyarakat, tentu saja hal ini berkait dengan frasa "...dan pengurus Organisasi Advokat lainnya..." pada poin 6 Surat Ketua Mahkamah Agung RI No 73/KMA/HK.01/IX/2015. Frasa demikian diametral terhadap orginal intent pembentukan wadah tunggal organisasi advokat yang telah direalisasi oleh delapan organisasi pada 21 Desember 2004, sebagaimana amanat Pasal 32 ayat (3) UU Advokat dengan nama PERADI.

Pada kulminasi demikian, wadah tunggal organisasi advokat merupakan keinginan masyarakat pencari keadilan yang dipositifkan oleh para wakil rakyat melalui proses legislasi dan tidak membenarkan, atau dilarang oleh kehendak masyarakat, ketika organisasi advokat demikianternyata justru beragam dalam banyak wadah organisasi.

Mengenai aspek "menentukan kemampuan terhadap perbuatan," poin ini yang agaknya mengandung parsialitas. Harus dicermati bahwa dasar adanya tindak pidana adalah asas legalitas, sedangkan dasar dapat dipidananya sang pelaku (pembuat) adalah asas kesalahan. Pada konteks asas legalitas, jelas terlihat bahwa Surat Ketua Mahkamah Agung RI No 73/KMA/HK.01/IX/2015 telah menabrak ketentuan UU Advokat yang berulang kali disebut dengan diksi "undang-undang ini." Diksi tersebut sejatinya menunjukkan asas legalitas dari UU Advokat sebagai rule of the game yang bersifat lex scripta, lex stricta, lex certa dan lex preivia atas pembentukan wadah tunggal organisasi advokat; PERADI. Namun demikian, asas kesalahan atas terbitnya Surat Ketua Mahkamah Agung RI No 73/KMA/HK.01/IX/2015 menjadi bias karena ketiadaan sanksi pidana 
dalam UU Advokat ketika ketentuan wadah tunggal organisasi advokat disimpangi oleh lembaga lain.

Pada konteks isu hukum demikian, MA yang menginstruksikan kepada seluruh Ketua Pengadilan Tinggi yang notabene diberikan kewenangan melakukan sumpah advokat dalam sidang yang terbuka sebagaimana ketentuan Pasal 4 ayat (1) UU Advokat. Pada ulasan demikian, meskipun penyimpangan atas asas legalitas terpenuhi, namun tidak demikian dengan asas kesalahan, sehingga hal ini mengandung arti bahwa pembuat atau pelaku tindak pidana hanya dapat dipidana apabila yang bersangkutan mempunyai kesalahan dalam melakukan tindak pidana tersebut.

Mengutip dari cara pandang gerakan studi hukum kritis memposisikan teks hukum merupakan dunia makna, diperlukan kesadaran kritis untuk memahaminya. Makna tidak dapat begitu saja tercermin dalam kumpulan teks, makna harus dibaca dengan kenyataan walaupun sepertinya terlalu rumit. Pekerjaan itu memerlukan keberanian sebagai upaya mengeluarkan kemapanan teks dari kebekuan dan kekakuan. ${ }^{27}$

Pertanyaan kritis yang muncul adalah kapan Ketua MA dikatakan mempunyai kesalahan ketika bentuk sanksi atas perbuatan yang telah dilakukan masih menyisakan kekosongan hukum, sedangkan kesalahan merupakan hal penting yang menyangkut masalah pertanggungjawaban pidana. Kekosongan hukum demikian tidak akan terjadi misalnya ketika mencermati ketentuan hukum di Rusia yang memiliki instrument hukum contempt of court apabila tidak menaati putusan atau perintah hakim. Pada KUHP Rusia, ${ }^{28}$ ketentuan contempt of court disobeying a court order di atur dalam Pasal 315 yang mengancam pidana sebagai bentuk delik karena sengaja tidak melaksanakan putusan atau tindakan yudisial yang notabene merupakan subjek hukum perwakilan otoritas dengan ancaman pidana denda 200 hingga 400 kali upah minimum yang diskualifikasi

\footnotetext{
${ }^{27}$ Faisal, "Membangun Politik Hukum Asas Legalitas Dalam Sistem Hukum Pidana Indonesia", Jurnal Huk.um Ius Quia Iustum, Nomor 1, Volume 21, Januari 2014, hlm. 83

${ }^{28}$ Fundamental Principles of the Criminal Legislation of the U.S.S.R. and Constituent Republics (CoL. Laws, U.S.S.R., 1924, No. 24).
} 
untuk jabatan tertentu, kerja sosial, kurungan tiga hingga enam bulan, bahkan pidana penjara sampai dua tahun ${ }^{29}$.

Lebih lanjut, menurut pendapat Simons, dasar pertanggungjawaban pidana adalah kesalahan yang terdapat pada jiwa pelaku dalam hubungannya (kesalahan itu) dengan perbuatan yang diancam dan dapat dipidana serta berdasarkan kejiwaan itu pelaku dapat dicela karena perbuatannya tersebut ${ }^{30}$.

Untuk menentukan adanya kesalahan pada pelaku, harus dicapai dan ditentukan terlebih dahulu beberapa hal yang menyangkut pelaku, yaitu: ${ }^{31}$ (1) kemampuan bertanggungjawab; (2) hubungan kejiwaan antara pelaku dan akibat yang ditimbulkan (termasuk pula perbuatan yang tidak bertentangan dalam hukum dalam kehidupan sehari-hari; (3) dolus dan culpa, pada titik ini kesalahan merupakan unsur subjektif dari tindak pidana.

Hal demikian ini tentu dapat dipahami sebagai konsekuensi dari pendapat Simons yang menghubungkan (menyatukan) straafbaarfeit dengan kesalahan. Poin kesalahan terbitnya Surat Ketua Mahkamah Agung RI No. 73/KMA/HK.01/IX/2015 agaknya mengalami bias ketika diperhadapkan dengan aspek "hubungan kejiwaan antara pelaku dan akibat yang ditimbulkan." Problematika wadah tunggal organisasi advokat demikian ternyata tidak serta merta dapat dipersalahkan ketika rule of the game dalam UU Advokat tidak mengatur jenis perbuatan demikian dengan ancaman sanksi pidana tertentu.

Mengenai unsur tindak pidana dalam ilmu hukum pidana, disebut juga elemen delik (unsur delik). Elemen delik tersebut merupakan bagian dari delik. Pada proses penuntutan sebuah delik, semua elemen delik yang dituduhkan kepada pelaku delik harus dibuktikan. Oleh karenanya, jika salah satu unsur atau elemen delik tidak terpenuhi, maka pelaku delik tidak dapat dipersalahkan telah

${ }^{29}$ Ancaman Pidana Contempt of Court di Indonesia diatur dalam ketentuan yang terdapat dalam KUHP yakni sebagai berikut Pasal 207, Pasal 217, Pasal 224. Kasus-kasus dan formulasi contempt of court di Indonesia pada umumnya hanya terbatas pada penghinaan secara verbal maupun tertulis, membuat kegaduhan dan tidak memenuhi panggilan peradilan.Lilik Mulyadi dan Budi Suharryanto, Contempt of Court di Indonesia Urgensi, Norma, Praktik, Gagasan \& Masalahnya, Alumni, Bandung, 2016, hlm 116

30 Simon mengemukakan 'Als grondslag voor de strafrechtelijke toerekening bestaat zij in de psychische gestedheid van de dader en hare betreking tot de ter beoordeeling staande handeling en wel in dien zin, dat op grond van die gestelheid aan de dader van zijn handelen een verwijt mag worden gemaakt D. Simon, Leerboek Van Het Nederlandsche Strafrecht, Eerste Deel, Zesde Druk, P. Moordhoof, N.V.-Groningen-Batavia. h.187-188

${ }^{31}$ Oemar Seno Adji, Etika Profesional dan Hukum Pertanggungjawaban Pidana Dokter, Erlangga, Jakarta, 1991, $h \operatorname{lm} 34$. 
melakukan delik yang dituduhkan. Pada akhirnya, pelaku delik harus dilepaskan dari segala tuntutan hukum (onslaag van rechts alle vervologing).

Elemen delik umumnya terbagi dalam dua bagian, yaitu: (1) unsur objektif atau yang biasa disebutactus reus dan (2) unsur subjektif atau yang biasa disebut mens rea. ${ }^{32}$ Unsur objektif delik merupakan unsur-unsur yang ada hubungannya dengan keadaan-keadaan, yaitu dalam keadaan-keadaan seperti apa yang menggambarkan tindakan-tindakan dari pelaku. Sedangkan unsur objektif dari tindak pidana meliputi: (a) sifat melawan hukum, (b) kualitas dari pelaku, dan (c) kausalitas, yaitu hubungan antara sesuatu tindakan sebagai penyebab dengan kenyataan sebagai akibat.

Elemen delik objektif adalah elemen delik yang berkaitan dengan perbuatan (act, daad) dari pelaku delik, yaitu: (1) wujud perbuatan (aktif, pasif) atau akibat yang "kasat mata". Suatu delik dapat diwujudkan dengan kelakuan aktif atau juga kelakuan pasif sesuai dengan uraian delik yang mensyaratkannya.

Terbitnya Surat Ketua Mahkamah Agung RI No. 73/KMA/HK.01/IX/2015 ditinjau dari wujud perbuatannya, jelas merupakan perbuatan aktif dalam jenis delik delictum commissionis per ommissionem commissa atau delik tidak menaati larangan dilanjutkan dengan cara tidak berbuat demikian. Perbuatan penerbitan Surat Ketua Mahkamah Agung RI No. 73/KMA/HK.01/IX/2015 sebagaimana telah dikemukakan merupakan bentuk sifat melawan hukum.

Perbuatan yang disyaratkan untuk memenuhi elemen delik objektif adalah bahwa dalam melakukan suatu perbuatan, harus terdapat elemen melawan hokum (wedderectelijkheids, unlawfull act, onrechtma-tigedaad). Sebagaimana diuraikan sebelumnya, suatu perbuatan melawan hukum merupakan perbuatan yang dilarang untuk dilakukan, atau diperintahkan untuk tidak dilakukan, seperti yang tercantum dalam aturan pidana. Namun demikian, dikarenakan UU Advokat tidak memformulasikan ancaman pidana beserta sanksinya berkait suatu perbuatan melawan hukum yang dilakukan, maka dapat dipahami bahwa penyusunan perbuatan melawan hukum demikian masuk dalam kategori perbuatan melawan hukum materiil. 
Ditegaskan bahwa wederrechtelijk disebut materiil karena sekalipun suatu perbuatan telah sesuai dengan uraian di dalam undang-undang, masih harus diteliti tentang penilaian masyarakat apakah perbuatan itu memang tercela dan patut dipidana pembuatnya atau tidak tercela, atau dipandang sifatnya terlampau kurang celaannya sehingga pembuatnya tidak perlu dijatuhi sanksi pidana, tetapi cukup dikenakan sanksi dalam kaidah hukum lain atau kaidah sosial lain. Pada hal inilah penerbitan Surat Ketua Mahkamah Agung RI No. 73/KMA/HK.01/IX/2015, meskipun terkategori sebagai perbuatan melawan hukum materiil, tidak mencukupi jika dikaitkan dengan unsur asas culpabilitas (penentuan kesalahan pembuat delik) atau nilai keadilan hukum yang ada dalam masyarakat dan tingkat kepatutan serta kewajarannya.

Hal lain yang relatif menyulitkan ulasan kesalahan terbitnya Surat Ketua Mahkamah Agung RI No. 73/KMA/HK.01/IX/2015 yaitu berkenaan dengan bahasan ketiadaan dasar pembenar terbitnya surat dimaksud. Pada optik teoretis, suatu perbuatan dikualifikasikan telah memenuhi terjadinya delik, yaitu ketika dalam perbuatan tersebut tidak terkandung dasar pembenar, sebagai bagian penting dari elemen delik objektif (actus reus). Dasar pembenar merupakan dasar yang menghilangkan sifat melawan hukum dari perbuatan yang sudah dilakukan pembuat delik. Artinya, jika perbuatan itu mengandung dasar pembenar, maka salah satu unsur delik (elemen delik) objektif tidak terpenuhi. Akibatnya, pelaku (pembuat) delik tidak dapat dikenakan pidana. Penerbitan Surat Ketua Mahkamah Agung RI No. 73/KMA/HK.01/IX/2015 yang merinci konsideran dan dasar hukum sebelum menerbitkan surat tersebut, menempatkan surat tersebut memiliki dasar pembenar ${ }^{33}$ yang relatif kuat. Dengan demikian Surat Ketua Mahkamah Agung RI No. 73/KMA/HK.01/IX/2015 direfleksikan sebagai pelaksanaan perintah jabatan yang berwenang.

${ }^{33}$ Membaca ketentuan KUHP dengan seksama, terdapat beberapa jenis Dasar Pembenar, yaitu: (1).Daya Paksa Relatif (vis compulsiva), (2).Pembelaan Terpaksa, (3).Melaksanakan Perintah Undang-Undang, dan (4).Melaksanakan Perintah Jabatan yang Berwenang. R.Soesilo, Kitab Undang-undang Hukum Pidana (KUHP) Serta Komentar-komentarnya Lengkap Pasal Demi Pasal, Bogor: Politeia, hlm 63-66. Adapun mengenai konsideran Surat Ketua Mahkamah Agung dapat disebutkan bahwa "sehubungan dengan banyaknya surat yang masuk ke Mahkamah Agung dari berbagai Pengurus Advokat dan perorangan maupun lembaga negara tentang penyumpahan Advokat dan terkait Putusan Mahkamah Kosntitusi Nomor 101/PUU-VII/2009 tanggal 29 Desember 2009 serta Surat Ketua Mahkamah Agung Nomor 089/KMA/VI/2010 tanggal 25 juni 2010 tentang Penyumpahan Advokat jo Nomor 052/KMA/HK.01/III/2011 tanggal 23 Maret 2011 tentang Penjelasan Surat Ketua Mahkamah Agung Nomor 089/KMA/VI/2010" 
Analisis Potensi Perbuatan Melawan Hukum Pidana dan Pertanggungjawaban Hukum Pidana atas Pengusulan Sumpah Advokat kepada Pengadilan Tinggi oleh Organisasi Advokat Selain PERADI pasca-Putusan Mahkamah Konstitusi Nomor 35/PUU-XVII/2018

Mencermati konsistensi putusan Mahkamah Konstitusi dari waktu ke waktu dengan tarik ulur organisasi advokat yang terus saja disoal, ini sejatinya menunjukkan polemik yang tegas mengenai eksistensi PERADI sebagai wadah tunggal organisasi advokat. Oleh karenanya, ketika terdapat upaya pengusulan sumpah advokat ke Pengadilan Tinggi oleh Organisasi Advokat selain PERADI pasca-putusan Mahkamah Konstitusi Nomor 35/PUU-XVII/2018, perbuatan melawan hukum pidana yang dapat dimintai pertanggungjawaban hukum pidana atas perbuatan pengusulan tersebut berpotensi terjadi.

Ketika terdapat berbagai organisasi advokat selain PERADI yang tidak dapat memenuhi tiga kriteria sebagaimana diatur dalam UU Advokat, maka dapat dipastikan terjadi benturan dengan ketentuan perundangan yang notabene dilingkupi asas legalitas. Ketiga kriteria tersebut adalah (a) waktu pendirian (time of establishment) Organisasi Advokat; (b) subjek hukum (subjectum juris) yang mendirikan Organisasi Advokat; dan (c) hanya ada satu Organisasi Advokat.

Ketika berbagai organisasi advokat selain PERADI mengusulkan atau mengajukan permohonan penyumpahan advokat kepada Pengadilan Tinggi sesuai domisili, yang terjadi selanjutnya tentu saja benturan dengan ketentuan wadah tunggal organisasi advokat (hanya ada satu organisasi advokat) sebagaimana termaktub pada Pasal 28 ayat (1) UU Advokat. Hal lain yang dapat dipastikan tidak akan dapat dipenuhi oleh beragam organisasi advokat selain PERADI, yaitu berkenaan Pasal 32 ayat (4) UU Advokat. Pada konteks pasal ini, telah ditentukan bahwa dalam waktu paling lambat dua tahun setelah berlakunya UU Advokat, Organisasi Advokat telah terbentuk.

UU Advokat diundangkan pada 5 April 2003. Karena itu, Organisasi Advokat didirikan paling lambat 5 April 2005. Pada kurun waktu dua tahun ini, hanya PERADI yang berproses dan pada akhirnya didirikan pada 21 Desember 2004. Mengenai subjek hukum yang mendirikan organisasi advokat, hal demikian tentu saja juga tidak mungkin dapat dipenuhi oleh organisasi di luar PERADI. 
Sesuai Pasal 32 ayat (3) UU Advokat, ada delapan Organisasi Advokat yang melakukan tugas sementara hingga dibentuknya Organisasi Advokat, yaitu Ikatan Advokat Indonesia (Ikadin), Asosiasi Advokat Indonesia (AAI), Ikatan Penasihat Hukum Indonesia (IPHI), Himpunan Advokat dan Pengacara Indonesia (HAPI), Serikat Pengacara Indonesia (SPI), Asosiasi Konsultan Hukum Indonesia (AKHI), Himpunan Konsultan Pasar Modal (HKPM) dan Asosiasi Pengacara Syariah Indonesia (APSI). Kedelapan Organisasi Advokat inilah yang mendirikan PERADI, pada 21 Desember 2004 yang notabene masih dalam tenggang waktu yang ditentukan oleh UU Advokat.

Ketika beragam ketentuan dalam UU Advokat dimaksud tidak dapat dipenuhi, maka upaya pengajuan sumpah advokat oleh organisasi di luar PERADI dapat dikategorikan sebagai PMH materiil atau disebut juga "melawan hukum secara umum" sebagai akibat dilakukannya perbuatan tanpa kewenangan. ${ }^{34}$ Wederrechtelijk materiil merupakan sesuatu perbuatan yang dikategorikan wederrechtelijk, walaupun tidak dengan tegas dilarang dan diancam dengan hukuman oleh undang-undang, melainkan juga mencakup asas-asas umum yang terdapat di dalam lapangan hukum (algemen beginsel). Namun demikian, meskipun seseorang maupun suatu badan hukum melakukan perbuatan pidana, tidak selalu yang bersangkutan dapat dipidana. Hal demikian dapat terjadi ketika ketentuan undang-undang yang disimpangi tidak mengatur secara rinci mengenai perbuatan apa yang dilarang dan perbuatan tersebut diancam dengan sanksi pidana tertentu.

Meskipun perbuatan seseorang atau badan hukum telah terbukti melawan hukum pidana, tetapi jika aspek kesalahan tidak terpenuhi sebagai akibat formulasi yang tidak rinci atas undang-undang yang disimpangi, maka pemidanaan tidak dapat dilakukan. Pada konteks bahasan ini, ketiadaan unsur kesalahan yang notabene menjadi salah satu komponen utama pertanggungjawaban hukum pidana atas pengusulan sumpah advokat ke pengadilan tinggi oleh organisasi advokat selain PERADI pasca-Putusan Mahkamah Konstitusi Nomor 35/PUU-XVII/2018, ini menyebabkan pertanggungjawaban hukum pidana sulit diwujudkan. Lain halnya jika

${ }^{34}$ Eddy O.S. Hiariej, Prinsip-prinsip..., Op. Cit., hlm. 190-192 
pengusulan sumpah advokat demikian berujung pada dirugikannya hak calon advokat sebagai konsekuensi tidak berwenangnya organisasi di luar PERADI untuk mengusulkan sumpah advokat kepada pengadilan tinggi sesuai domisilinya. Maka, ketika timbul unsur kesalahan akibat kerugian yang diderita seseorang, maka formulasi ketentuan KUHP dapat digunakan dalam pemenuhan unsur kesalahan yang dilakukan oleh organisasi di luar PERADI tersebut.

Jika kondisi pemenuhan unsur kesalahan demikian terwujud, maka pada konteks tersebut, pertanggungjawaban hukum pidana atas pengusulan sumpah advokat ke pengadilan tinggi oleh organisasi advokat selain PERADI pascaPutusan Mahkamah Konstitusi Nomor 35/PUU-XVII/2018 menjadi sebab pertanggungjawaban hukum pidana dapat diwujudkan.

\section{Penutup}

Berdasarkan uraian dan analisis yang sudah diketengahkan sebelumnya, dapat ditarik suatu kesimpulan bahwa;

1. Terbitnya Surat Ketua Mahkamah Agung RI No. 73/KMA/HK.01/IX/2015 perihal penyumpahan advokat terkategorisasi memunculkan perbuatan melawan hukum pidana, utamanya perbuatan melawan hukum pidana materiil. Namun demikian, pertanggungjawaban hukum pidananya sulit diwujudkan karena rumusan yang tidak detail berkenaan dengan unsur pasal yang dilanggar atas undang-undang yang disimpangi. Hal demikian juga diperkuat karena hingga saat ini di KUHP Indonesia belum mengatur ketentuan mengenai contempt of court disobeying a court order.

2. Ketika organisasi advokat selain PERADI melakukan pengusulan sumpah advokat ke Pengadilan Tinggi, hal demikian dapat dikategorikan telah melakukan perbuatan melawan hukum pidana materiil. Namun demikian, pertanggungjawaban hukum pidananya sulit diwujudkan jika yang disasar hanyalah penyimpangan atas UU Advokat. Hal ini karena adanya rumusan yang tidak detail berkenaan dengan unsur pasal yang dilanggar di dalam UU Advokat, meskipun sudah ada Putusan Mahkamah Konstitusi Nomor 35/PUU-XVII/2018. Lain halnya jika pengusulan sumpah advokat demikian berujung pada dirugikannya hak calon advokat sehingga dapat digunakan 
formulasi ketentuan KUHP dalam pemenuhan unsur kesalahan yang dilakukan oleh organisasi di luar PERADI tersebut.

Adapun saran dari hasil penelitian ini adalah;

1. Mencermati kajian yang menemukan adanya kekosongan hukum berkenaan dengan ketentuan contempt of court disobeying a court order, maka diperlukan formulasi pada ketentuan hukum pidana normatif (KUHP). Pada aspek yang lebih luas, telaah mengenai hukum pidana yang seharusnya mencakup masa kini dan masa mendatang, maka diperlukan kajian mendalam terhadap bidang ilmu hukum pidana mengenai kebijakan atau politik hukum pidana (strafrechtspolitiek) atau yang dikenal dengan istilah penal policy atau disebut juga criminal law policy.

2. Berdasarkan hal tersebut, maka diperlukan sebuah pembaruan hukum pidana di Indonesia pada umumnya dan pada khususnya adalah mengenai contempt of court disobeying a court order, yang tentunya hal ini berkaitan juga dengan kebijakan kriminal. Kajian dan telaah demikian demi menjamin penyelenggaraan negara berdasarkan hukum dan kewibawaan pengadilan, kekuasaan kehakiman yang merdeka tanpa intervensi lembaga lain sehingga terciptanya kepastian, keadilan serta kemanfaatan hukum pada formulasi ius constituendum.

\section{Daftar Pustaka}

\section{Buku}

Adji, Oemar Seno, Etika Profesional dan Hukum Pertanggungjawaban Pidana Dokter, Erlangga, Jakarta, 1991.

Farid, H.A. Zainal Abidin, Hukum Pidana I, Sinar Grafika, Jakarta, 2007.

Fuady, Munir, Perbuatan Melawan Hukum (Pendekatan Kontemporer). PT. Citra Aditya Bakti, Bandung, 2005.

Faisal, Politik Hukum Pidana, Rangkang Education, Tangerang, 2020.

Hamzah, Andi, Pengantar dalam Hukum Pidana Indonesia, Yarsif Watampone, Jakarta, 2010.

Huda, Chairul, Dari Tiada Pidana Tanpa Kesalahan Menuju Kepada Tiada Pertanggungjawaban Pidana Tanpa Kesalahan, Kencana Prenada Media, Jakarta, 2006. 
Hiariej, Eddy O.S. Prinsip-prinsip Hukum Pidana, Cahaya Atma Pustaka-UAJY, Yogyakarta, 2014.

Hamel, G.A. van, Inleiding Tot De Studie Van Het Nederlansche Strafrecht, Derde Druk, De Erven F. Bohn Haarlem \& Gebr. Belinfante's-Gravenhage, 1913.

Kartanegara, Satochid, Hukum Pidana Bagian Pertama, Balai Lektur Mahasiswa, Jakarta, 1955.

Mulyadi, Lilik, dan Budi Suharryanto, Contempt of Court di Indonesia Urgensi, Norma, Praktik, Gagasan \& Masalahnya, Alumni, Bandung, 2016.

Otto, Jan Michiel, terjemahan Tristam Moeliono dalam Shidarta, Moralitas Profesi Hukum Suatu Tawaran Kerangka Berfikir, PT Revika Aditama, Bandung, 2006.

Priyatno, Admaja, Kebijakan Legislasi Tentang Sistem Pertanggungjawaban Pidana Koorporasi di Indonesia, CV. Utomo, Bandung, 2004.

Rahayu, Derita Prapti dan Sulaiman, Metode Penelitian Hukum, Thafa Media, Yogyakarta, 2020.

Soesilo, R. Kitab Undang-undang Hukum Pidana (KUHP) Serta Komentar-komentarnya Lengkap Pasal Demi Pasal, Politeia, Bogor, 1996.

Simon, D. Leerboek Van Het Nederlandsche Strafrecht, Eerste Deel, Zesde Druk, P. Moordhoof, N.V.-Groningen-Batavia.

Jurnal

Faisal, "Menelusuri Teori Chaos Dalam Hukum Melalui Paradigma Critical Theory", Jurnal Hukum Yustisia, Volume 3 Nomor 2, Mei-Agustus 2014

"Membangun Politik Hukum Asas Legalitas Dalam Sistem Hukum Pidana Indonesia", Jurnal Hukum Ius Quia Iustum, Nomor 1, Volume 21, Januari 2014.

Maulani, Diah Gustiniati, "Analisi Pertanggungjawaban Pidana dan Dasar Pemidanaan Terhadap Pelaku Tindak Pidana Penodaan Agama Di Indonesia", Fiat Justitia Jurnal Ilmu Hukum, Volume 7 Nomor 1, JanuariApril 2013

Samosir, Samuel Saut Martua, "Organisasi Advokat dan Urgensi Peran Pemerintah dalam Profesi Advokat", Jurnal Konstitusi, Volume 14, Nomor 3, September 2017

Sriyanto, I., "Asas Tiada Kesalahan dalam Pertanggungjawaban Pidana dengan Penyimpangannya", Jurnal Hukum dan Pembangunan,Nomor 2 Tahun XXIII, April 1993.

Rustamaji, Muhammad. "Simulacra Asas Praduga Tidak Bersalah dalam Ingsutan Kewenangan Praperadilan" Yustisia Jurnal Hukum, Volume5, Issue2, 2016. 
Makalah dan Tulisan Lain

Sinurat, Lusius, 'Simulacra dan Realitas Semu', www.lusiussinurat.com/2013/07/simulacra-dan-realitas-semu, diunduh 8 Oktober 2019.

\section{Putusan Pengadilan}

Putusan Mahkamah Konstitusi Nomor 014/PUU-IV / 2006

Putusan Mahkamah Konstitusi Nomor 101/PUU-VII/2009

Putusan Mahkamah Konstitusi Nomor 66/PUU-VIII/2010

Putusan Mahkamah Konstitusi Nomor 112/PUU-XII/2014

Putusan Mahkamah Konstitusi Nomor 36/PUU-XIII/2015

Putusan Mahkamah Konstitusi Nomor 35/PUU-XVII/2018

Surat Ketua Mahkamah Agung RI No 73/KMA/HK.01/IX/2015

Surat Ketua Mahkamah Agung Nomor 089/KMA/VI/2010 tanggal 25 juni 2010 tentang Penyumpahan Advokat

Surat Ketua Mahkamah Agung Nomor 052/KMA/HK.01/III/2011 tanggal 23 Maret 2011 tentang Penjelasan Surat Ketua Mahkamah Agung Nomor 089/KMA/VI/2010

\section{Peraturan Perundang-undangan}

Fundamental Principles of the Criminal Legislation of the U.S.S.R. and Constituent Republics (CoL. Laws, U.S.S.R., 1924, No. 24).

Undang-Undang No. 31 Tahun 1999 Jo. Undang-Undang No. 20 Tahun 2001 tentang Pemberantasan Tindak Pidana Korupsi (UU Tipikor)

Undang Undang Nomor 18 Tahun 2003 tentang Advokat 